\title{
Postcolonial Realities in Ben Okri's the Famished Road and Songs of Enchantment
}

\author{
Oko Eze Ernest* \\ Department of English University of Abuja, Nigeria.
}

*Corresponding Author: Oko Eze Ernest, Department of English University of Abuja, Nigeria.

\begin{abstract}
This paper examines postcolonial realities in Ben Okri's The Famished Road and Songs of Enchantment. These texts are subjected to textual analyses, using postcolonial theory as a springboard, with a view to explicating the postcolonial realities in post-independence Nigeria. These postcolonial realities shed light on the characters and the thematic concern of Ben Okri. The paper reveals how Okri uses the myth of abiku( spirit child) to highlight the postcolonial realities in Nigeria; that is, incorporating the spirit world with the real world. Both novels capture the Nigerian society where the magnitude of corruption and other social vices are very high. The novels also show one group trying to impose its belief on the other, while the oppressed seems to counter the belief system of the dominated class. This paper, therefore, reiterates and concludes on how Okri uses the intrinsic features of prose fiction to explicate the Nigerian postcolonial realities in the novels.
\end{abstract}

Keywords: Postcolonial, Abiku, Realities, Nigeria, Ben Okri.

\section{INTRODUCTION}

Literature pictures life in a way to bring out the expected values and realities in man and the society. It captures the complex forms of engagement between the different components of a society and its people. Some literary critics, such as Mary Kolawole (2005:9), and Ayo Kehinde and Joy EbongMbipom (2011:62) buttressed this assertion, as they suggest that literature is not only an imitation of life, but also a concept which derives from certain sustainable principles. It is one of these principles that this paper attempts to discuss; that is, postcolonial realities in the chosen novels. Postcolonial realities is used in this paper to refer to human lives and experiences, which most postcolonial writers attempt to explicate in their works, and Ben Okri is not an exception. It is also common among African writers to reflect and narrate the African experiences, and issues that are associated with post-colonialism. Hardship, hunger, unemployment, depression, penury and oppression are recurrent motifs of postcolonial African states. These, among others are the contentions of this paper.

Nigeria, for instance, political independence seems to have brought neither peace nor prosperity to the country, rather, it paradoxically has borne witness to economic stagnation and to what J.F Ade Ajayi, in Oko (2010) terms an 'obsession with politics' for its own sake. He says:

The most fundamental aspects of post-independence Nigeria has been the elusiveness of development, however characterised... that is to say, in many ways the quality of life of the average farmer and family in the village, or a worker in the urban areas, has not improve significantly; in the same respects, and in some areas, it's even worse than on the eve of independence. In particular, Nigeria now finds it difficult to provide for her populations sufficient food and energy resources for their basic necessities of life. Nigeria is yet to evolve stable political structures that are imbued with a sense of national commitment; notions of social justice, around which loyalties of masses could be mobilised. Rather, the uneven development between cities and rural areas of the same region persists. In addition, the inequalities of income distribution that characterised colonial rule have tended to widen considerably since independence. As a result there have been civil unrest and civil war, and there is general less security for life and 
property. In a few cases, grotesque and abnormal regimes have emerged that prey on their own people rather than protect them or promote their welfare (9).

This is also a point buttressed by Achebe (1983), when he says:

The trouble with Nigeria is simple and squarely a failure of leadership.There is nothing wrong with the Nigerian land or climate or water or air or anything else. The Nigerian problem is the unwillingness or inability of its leader to rise the responsibility... (1).

However, the novels that are considered in this essay x-ray the plights of Nigerian nation which after imperialism and colonialism still continue to struggle and groan under the problem of neocolonialism. These novels categorise the postcolonial Nigerian nation into two different groups: the rich and the poor. Okri uses these novels to reveal the mood of disillusionment, which is a seemingly permanent feature of the postcolonial African experience. According to Ashcroft Bill, Garath Griffiths and HellenTiflin (1989)"postcolonial writing defines itself by seizing the language of the centre and replacing it in a discourse fully adapted to the colonised place" (37). This replacement is achieved through appropriating and abrogating some of the colonisers 'language to give to the postcolonial experiences and realities of the colonised. The above assertion accounts for Okri's choice of the myth of $a b i k u$, and the road which is always famished. Okri relates these mythical worlds of abiku, the road, and sorcery to the instability in the country (Nigeria).

The main thematic concerns of the postcolonial African novel consequently include a criticism of the realities of post-independence (Kehinde, 2005:87). Therefore, the major theme of the two works considered in this paper is the failure of postcolonial Nigeria to live up to the dreams which inspired the struggle for independence from the European rule and subsequently brought on by the African leaders. To Okri, the rulers, due to corruption and ineptitude, have betrayed the hopes with which the new nation approached independence. He has exploited his imaginative resource to put a mirror to the tragedy of this African situation (Nigeria in particular).

The Myth of Abiku

It should be reiterated that Okri shows a proclivity for the Myth of abiku, the spirit-child, who ushers the gates to the worlds of the novels. Adeniji (2008) fore-grounded the myth of abiku thus: the word abiku which is the most important word in the myth of abiku ordinarily means "children-born-to-die-young" in the Yoruba language (a tribe in the south-western Nigeria) (240) "my emphasis".

Thus, to refer to someone as an abiku, for instance, Azaro and Ade in the texts under study, is to transfer the uncanny ability to die young and be born againto that person. Within the Yoruba culture, this word has a negative connotation as a person so named is seen as a bringer of death and sorrow to the household. Abiku also stands for a transcendental presence in that it implies somebody who is capable of existing in the physical and spiritual realms simultaneously. This feature makes the abiku an interesting even if not desirable character within the culture. Okri uses the quasi-positive aspect of the word abiku by translating it as "spirit-children" and creating an enchanting world for the abiku in his prose fiction. In one breath, therefore, the word abiku stands for two clearly opposite meanings: mortality and immortality. These two phenomena, life and death are perennial burdens of all human being irrespective of race and religion. Therefore, to call someone an abiku is confer on the person both morality and immorality. The aforementioned composite meanings associated with the myth of abiku gives us an in-depth understanding of the term, as we encounter it in this paper.

\section{The Famished Road}

It is narrated by Azaro, aspirit-child or abiku, who is compelled to move between the human and spirit realms, acting as a witness to his family's (country's) chaotic history. It is a story rich in fantastical and metaphorical elements, while also charting Nigeria's economic and political corruption and human effects of war.

In The Famished Road and Songs of Enchantment, Okri evokes the milieu of the poor and downtrodden and invests them with the special imaginative capacities of an abiku. This milieu of the poor is expanded by Kehinde (2004), thus:

The postcolonial African writers portray the ordeals of the ordinary citizens of their societies who wallow in abject poverty and tattered penury... They depict their 
continent as a society characterised by misery, squalor, oppression, diseases and overcrowding (97).

The portrayal of cultural and socio-political realities in The Famished Road, capture some critics view-points that see the novel as a postcolonial work, which is not different from the preoccupation of this paper. According to Harry Garuba (1993), " despite the background of myth and magic, The Famished Road is not a fable set in a never, never, world of fantastic trivia, but agrim socio-economic tale of poverty and politics of a neo-colonial state" (23).Garuba, however, sees postcolonial considerations as the main burden of Okri in the novel. The novel is apocalyptic or, prophetic. The much agitation for independence would not be achieved as it would not translate into total freedom. The rich would 'recolonise' the poor: ' Blindness. And then when the people expect it a great transformation ......" (478). These, undoubtedly, suggest postcolonial realities.

Okri, through his skilful handling of the respective myths, including that of reincarnation, as well as that of the biblical Lazarus (Azaro), is able to portray the realities of the present-day Nigerian society and institutions. Since her independence (Nigeria), there have been a lot of political and economic instabilities from one political culture or government to another. These political and economic instabilities can be likened to the spirit-child or abiku and its incessant coming and going, as it is the case in The Famished Road. All these are directly connected to the Nigerian nation and her historical background. The novel portrays the instability in the Nigerian nation, and this is what the narrator deconstructs in the riddle thus:

The spirit child is an unwilling adventurer into chaos and sunlight, into the dream of the living and the dead. Things that are not ready, not willing to be born or to become, things for which adequate preparations have not been made to sustain their momentous births, things that are not resolved....... They keep coming and going till their time is right. History itself fully demonstrates how things of the world partake of the condition of the spirit-child (487).

This is the condition that Nigeria is subjected to, that is, "the spirit child's condition."

"They (Abikus) keep coming and going till their time is right"(487). From the foregoing it can be affirmed that the nation's authentic independence, which is likened to abiku's condition, is yet to be achieved. Moreover, one of the living abikus, Ade, who is also pessimistic about the condition of the Nigeria, also attests to it. He says:

Our country is an abiku country like the spirit-child, it keeps coming and going. One day it will decide to remain. It will become strong I won't see it. His voice changed, became more natural almost gentle (478).

Ade in the above lines is of the view that one day Nigeria as a nation will be stable with her reform policies, but this is a prophecy he will not live to witness. He (Ade) is like one of the founding fathers of the Nigerian nation who fought for the unity and stability of the country but was cut short by death. Consequently, the description of the threeabikus in Madame Koto's belly and their position has a strong signification in relation to Nigeria. It is through Azaro's super-sensory telepathic and clairvoyant power that, this description is made clear to the reader. He says:

And I saw that Madame Koto was pregnant with three strange children. Two

of them sat upright and the third was upside down in her womb. One of them

had a little beard, the second had fully formed teeth, and the third had wicked

eyes. They were mischievous, they kicked and tugged at their cords, they were

the worst type of spirit-children, and they had no intention of being born.

Madame Koto straightened, came over to me, and said: 'Why were you

staring at my stomach like that with your bad-luck eyes'?(464).

The excerpt above, even Madame Koto knows that Azaro brings bad-luck and misfortune to his parents (Nigeria). Azaro is likened to the echo of independence and its attendant problems. 'This independence has brought only trouble' (169).Azarois the embodiment of the Nigerian nation that has been born. The three other abikus are Azaro's extension, and their refused to be born is their inability to become a nation of their own. Going by the disposition of the three abikus in the belly, as observed 
by Azaro, it is better for them not to be born. Through Azaro, decides to stay, he still struggles with existence. It suggests that Nigeria suffers because 'adequate preparations have not been made to sustain their momentous births' (487), 'what will be the case of the three abikus that he depicts as the worst type of the spirit-children?' (464). '.... they had no intention of being born, but any attempt to force them to be will lead to another blood and betrayed' (civil war) (496).

The rain God was merciless for two weeks. It rained so much that the sky seemed to have become as inexhaustible with water as the seas. At night water leaked through over ceiling, which we sworn discovered was full of holes... sometimes in the morning we would wake up and find slugs, worms, and millipedes crawling about the room. Little snails appeared on our walls, in containers we found tiny fishes (311).

The scenic presentation of Azaro's (Nigeria), household by the narrator equally portrays the level of poverty in the country. The poverty-stricken home of Azaro also depicts the poor, leadership quality that is common in the Nigeria. This leadership ineptitude erodes all efforts made to cut-off the relationship between Azaro (Nigeria) and the abiku world (the instability in the country).Though the problems in the country are not caused by us, they are handiwork of Nigeria's coloniser which created the Nigerian nation. These problems are foreseen by the herbalist when he prophesies that Azaro (Nigeria): "'this is a child who didn't want to be born, but also who will fight with death" (8). This explains that Nigeria as a nation would not have existed as a nation if not for the coloniser intervention. The diviner's prophecy is likened to Azaro's father dream. His dream attributed our problems to both the coloniser and the leadership ineptitude in our country. Azaro says:

He saw our people drawing in poverty in famine drought, in divisiveness and the blood of war. He saw our people always preyed upon by other powers manipulated by the western world, our history and achievements rigged out of existence. He saw the rich of our country, he saw the array of our politicians, how corruptible they were, how blind to our future, how greedy, they become (492).

This underscores that Nigeria as a nation has leaders who do not seek for her stability; rather they are interested in self-aggrandizement. They keep on acquiring wealth which they cannot use after all. "... how blind to our future" which, depicts the near death state of the nation and its epileptic status in policy formulations and implementations.

\section{Songs of Enchantment}

The sequel to The Famished Road, Songs of Enchantment, continues the story of the abiku, or spiritchild, Azaro and his hovering existence, caught in the middle space between the living and the dead. Azaro is still the narrator. It continues an apocalyptic vision of the African, nay Nigerian society, where the negligible few members of the wealthy class continue to dominate, oppress and pauperise the poor masses. It portrays a grim and chaotic society where the "haves" continue to re-colonise "the have-nots". Also in the novel, those perceived as opponents of the "neo-colonial masters are killed. Madame Koto in this novel is an embodiment of the neo-colonial masters. She is enchantress of the ghetto. Madame Koto's negative propensity is displayed in the way she oppresses the poor, especially Dad and Azaro in the narrative.

In the novel, the Carpenter, Ade's father, is killed by the thugs of Madame Koto, but his corpse is not buried. "The eagle vanished and a fountain of blood, thin and clear, burst from a vein in Ade's father's neck as one of the man stabbed him in the throat" (212). These lines share similar features with some of the political incidents in the Nigerian society. Ade's father agitates for the killing of his son, Ade, and he is equally murdered by thugs of Madame Koto. Besides, the Party of the Poor announces round the ghetto that, nobody should bury the corpse of the Carpenter expect the murderer. Thus, while the corpse continues to decompose beside the forest, the people of the ghetto refuse to bury it.

The action of the Party of the Poor shows that they are not in support of the murder of an innocent citizen in the ghetto, but their protest yield no result, subsequently, the people of the ghetto gather, and the corpse is summarily buried. By way of inference, the corpse is like a general problem of the people of the ghetto (Nigeria). Apart from the fact that the people of the ghetto are suffering a lot, they are oppressed by politicians that should have liberated them. The Party of the Rich terrorises and intimidates them so that they might give their support to the party. In essence; 
Okri accepts the fact that "suffering is one of the great characters of the book, the different ways people suffer'.... Anyone of the children telling their stories would be telling a story just like this one but with its own particularly. There are hundreds of variations, but there is just one god there, and that god is suffering, (Hawley 1995:27)

This is the suffering of Nigerians, who could recount their tales in hundredfolds. The ghetto (Nigeria) becomes the battle ground for many spirits fighting for the people's domination. The people are visited with epidemic, hunger, great pain and suffering.

Azaro encapsulates this view thus:

Everyone had concluded that suffering had unhinged the minds of the entire family. They also said that Ade had been bound twice for treatment. Small as he was, he had just free from the ropes and taken to roaming and the wild forest and the hot streets, his feet bleeding, sores on his shaven head, racing and shouting out curses, and frightening the birds and animals with his madness (187).

This explains how everybody in the society suffers; their houses and property are vandalised. For instance, Ade's family vacate their house because, it has been irreparably vandalised. The roof has fallen; the wall tilted, while the whole house is filled with water, amphibians and reptiles. This is why Ade's mother has to suffer a mental breakdown. His father runs into the bush and comes out later on to protest against the injustice, but is killed in a most dreadful way. This is one of the features of postcolonial Nigerian society, where there is high level of poverty and unwonted killing among the populace. Even Azaro's father has to condescend to carry loads, in order to feed his family. As for his wife, she suffers the scorching blaze of the sun. She walks on the road that has been made terribly hot by the fury of the sun while hawking her cheap wares.

Furthermore, Madame Koto, constitutes one of the impediments to the smooth growth of promising community (Nigeria). Ade, Azaro's spirit-child friend, makes an attempt at eliminating Madam Koto, who represents political tyranny, oppression, and domination. His dagger is only stuck her arm causing no fatal harm. Ade's attempt can be likened to several attempts that Nigerian government has made to sanitise the polity, through her reform policy, but has yielded no result. Ade, equally reiterated this, he knows that will fail "I failed" he continued. "I knew I would fail. My destiny was not to be an assassin, but a catalyst" (196). Ade's statement underscores that he shares the temperament of Nigerian nationalists who championed the cause of the Nigerian nation.

Besides, the attitude of Black Tyger shows an attempt to develop a political culture that is beneficial to the people and will be realistic. He out-rightly rejects the Party of the Rich because of its poseur, violence and egocentrism (which are the cases of many political parties in Nigeria). He realises that the Party of the Poor is closely aligned to that of the Rich in terms of unleashing violence on the people and causing fear to the ordinary people of the ghetto. To him, the two parties are two sides of a coin. He, thereafter, tries to develop his own to be independent of the existing two. He, therefore, puts the poor in the heart of his belief. He wants to house and educate them and provides all necessities of life. But he fails because his attempts are an existential daring of the enormous political decadence before him. His action can be likened as the doomed post-colonial cycle of Nigeria's historical destruction, and the failure of nationalist idealism and democratic ideology to survive political independence. Moreso, it can be deduced that Azaro could be considered as a metaphor for political, social and economic inadequacies of several places in Africa, more importantly, Nigeria. His deaths and rebirths could be likened to an attempt by many past and present Nigerian governments to evolve a viable political system that has met with a lot of frustration. The horrible situation remains the same, while people continue to nurse their sorrow and abject poverty in the Nigerian society. This is what Azaro reflects in this excerpt:

The ocean becomes calm. I saw the baby growing, and it saw me, and stared at me. I was knocked about in the old man's dream of a dying country that had yet been born, a nation born and dying from a lack of vision, too much greed and corruption, not enough love, too many divisions (91)

From the foregoing, Azaro dwells on the political situation in Nigeria which is challenged by abiku phenomenon, that is, "a nation born and dyingfromlack of visions, too much greed and corruption" 
(91). This attribute shares the same feature with most of Nigerian politicians. This political ineptitude has become an untold story; it seems to have become an order of the day within the polity. "Corruption came upon the people and grew fat. Diseases dwelled in them and misery had many children amongst them. The world turned upside down. Creation becomes confusion" (75). Beside Azaro decides to stay, and this is one of the challenges from which people of the world can draw a lesson particularly, Nigeria. Nigerians may have to widen the horizon of their knowledge to include an understanding of their spiritual universe. It is then they could boast of their capacity to break away from the cycle of ill-fortune adversely affecting the political and social realities in the society.

Also, Ade is aware of the ignoble role Madame Koto plays in the politics of the ghetto, and like Azaro, he wants toput an end to her savage era. Therefore, he attacks Madam Koto, but he is unsuccessful. He dies afterwards. It could be explained that his double standards rob his of the formidable power to kill the woman. He, of course, wants Madame Koto exterminated, and simultaneously continues to desire beyond the world of the living, thereby showing a non-committed attitude towards solving the socio-political problems. Apart from the likes of Azaro, Ade, Madame Koto, and Black Tyger there are other characters in Songs of Enchantment, that portray the woes of independence; the Masquerade, Yellow Jaguar, and other Miscellaneous spirits - as metaphors for the heartless, greedy and cruel rulers of the nation. It can alsobe reiterated that Black Tyger is a combination of Christ-like essence and the uncontrollable raw energy of Ogun: Yoruba god of war, as it is also evident in the novel (Adeniji, 2008)

\section{CONCLUSION}

This paper has considered and analysed the postcolonial realities in Ben Okri's The Famished Road and Songs of Enchantment. The human conditions are painstakingly x-rayed in the paper. This is the situation that engendered Okri to use the myth of (spirit child) to explicate the postcolonial realities in Nigeria. The novels employ a unique narrative style, incorporating the spirit world with the real world. Thus, Azaro's power to oscillate the two worlds captures the Nigerian society. Both texts capture the Nigeria society where the magnitude of corruption and other social vices are very high. For instance, the oppression and suppression of the 'Poor' by the 'Rich' in the two texts is a clear signification of the Nigeria situation. Azaro and his friend, Ade, represent the poor, while Madame Koto is an example of the "Rich" that oppresses the poor. Therefore, this paper expands how Okri uses the intrinsic elements of prose fiction to explicate the Nigerian postcolonial realities in the novels.

\section{REFERENCES}

[1] Achebe, C. The Trouble with Nigeria. Enugu: fourth Dimension, 1983, Print

[2] Adeniji, a "Myth and Realism in Ben Okri's Linguistic Aesthetics" OkoOkoro (Ed): Lagos Review of English Studies, 17\&2, 2008:16:28, Print.

[3] Ashcroft, Bill et al. The Empire writes back. London: Routledge, 1989, Print.

[4] Garuba, H. 'Ben Okri Animist Realism and famished Genre" The Guardian; Saturday 13March, 1993, 23 Print.

[5] Hawley, John C. 'Ben Okri Spirit-child: Abiku Migration and Post-Modernity', Research in African Literature. Spring: Indian University press, 26.1, 1995:20-29 Print.

[6] Kehinde, Ayo. "The Image of MejaMwangi's going Down River Road" Journal Culture Studies 6.1, 2004:94-113 Print.

[7] "Post-Independence Disillusionment in Contemporary African Fiction: The Example of MejaMwangi's Kill Me Quick" Nordic JournalofAfricanStudies13(2) 2004:228-241 Print

[8] 'Rethinking African Fiction in the Era of Globalization: A Nigerian English Contest of text and context " Journal of the Studies Association1.1,2005:87-97.Print

[9] Kehinde, Ayo andMbipom Joy Ebong "Discovery, Assertion and Self-Realisation in Recent Nigerian Migrant Feminist Fiction: The Example of Sefi Atta's Everything Good Will Come" African Nebula, Issue3, 2011:62-77 Print.

[10] Kolawole, Mary Text, Textuality and Contextuality: Paradigm Lost and Paradigms Regained in Literary Theory. IleIfe: Obafemi Awolowo University Press2005 Print.

[11] Mamudu, C.O Theorizing Magic realism in Latin American and African Literary Traditions: The Writing of Gabriel Garcia Marquez and Ben Okri, Unpublished M.A Thesis, Department of English, University of Ibadan 2001 Print. 
[12] Oko, Eze Ernest Animism in Ben Okri's The Famished Road and Songs of Enchantment, Unpublished M.A Thesis, Department of English, University of Ibadan 2010 Print.

[13] Okri, Ben the Famished Road. Ibadan: spectrum Books Limited 1991 Print.

[14] Songs of Enchantment. London: Vintage Books 1993 Print.

\section{AUTHOR'S AUTOBIOGRAPHY}

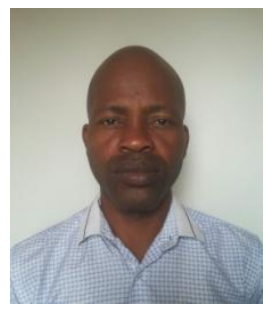

Oko Eze Ernest, is a doctorate student at the Department of English, University of Abuja, Nigeria. His areas of interest are African Literature, Literary theory, and African Oral tradition. He critiques works on African prose fiction dealing with disillusionment in post-independence Africa.

Citation: Oko Eze Ernest. Postcolonial Realities in Ben Okri's the Famished Road and Songs of Enchantment "International Journal on Studies in English Language and Literature (IJSELL), vol 8, no. 2, 2020, pp. 1-7. doi: http://dx.doi.org/10. 20431/2347-3134. 0802002.

Copyright: (C) 2020 Authors. This is an open-access article distributed under the terms of the Creative Commons Attribution License, which permits unrestricted use, distribution, and reproduction in any medium, provided the original author and source are credited. 